Teresa Olearczyk

ORCID: https://orcid.org/0000-0001-6660-2379

Krakowska Akademia im. Andrzeja Frycza Modrzewskiego w Krakowie

Najpierw trzeba uporzadkować siebie, potem inną, otaczajaca nas przestrzeń.

\title{
Przemiany polskiej rodziny i ich konsekwencje wychowawcze
}

\section{Wprowadzenie}

Kiedy mówimy o życiu współczesnej rodziny, warto podkreślić, że jest ono bardzo zróżnicowane. Żyjemy w epoce hałasu i chaosu - nie do końca uświadamiając sobie dalekosiężne przemiany, obejmujące wszystkie sfery życia społecznego, publicznego, a także rodzinnego. Następują przekształcenia pokoleniowe, generacyjne, żyjemy w epoce przejściowej, między epoką analogową a cyfrową.

Rodzina, przedmiot zainteresowań wielu dyscyplin nauki, jest najstarszą formą współżycia ludzi, istniejącą we wszystkich epokach, kulturach 
i społeczeństwach. Podstawę rodziny zawsze stanowiło małżeństwo - to wyróżniało ją od innych form współżycia ludzi. Rodzina monogamiczna jest typowa dla cywilizacji łacińskiej, akceptującej chrześcijańskie prawa i zasady moralne ${ }^{1}$. Podejście uniwersalistyczne w naukach społecznych przyjmuje, że rodzina jest normatywnie określoną grupą spokrewnionych osób, mającą na celu przede wszystkim wypełnianie zadań prokreacyjnych i socjalizacyjnych. Jej członkowie połączeni są więzami pokrewieństwa, określonymi przez małżeństwo. Za rodzinę uznaje się rodziny monoparentalne, z dziećmi poczętymi w związku lub adoptowanymi, małżeństwo zaś jest określonym związkiem kobiety i mężczyzny. Zarówno pedagodzy, jak i socjologowie uważają rodzinę za instytucję i grupę społeczną, która m.in. wychowuje dzieci².

Rozważając przeobrażenia zachodzące w rodzinie, począwszy od rodziny tradycyjnej, patriarchalnej, wielodzietnej, skończywszy na nowoczesnej, nuklearnej, mniej trwałej, należy wziąć pod uwagę, że jest ona bytem dynamicznym, ulegającym wpływom zewnętrznym; nie ma w niej rzeczy niezmiennych, poza wrodzonymi, uwarunkowanymi genetycznie, cechami wrodzonymi ${ }^{3}$.

Obraz współczesnej rodziny jest pośrednio naturalną konsekwencją wcześniejszych zmian, które przyczyniły się w znacznym stopniu do tego, jaka jest i w jakiej rzeczywistości funkcjonuje rodzina. Dokonane zmiany w rodzinie nie cofną się, poszerza się bowiem nurt związków niesakramentalnych, a także powtórnych związków małżeńskich, zawieranych po rozwodzie i po stwierdzeniu nieważności małżeństwa. Zresztą nie jest to nowość - Piłsudski np. zmieniał wiarę, by mógł zawierać kolejne związki. Prawo kanoniczne, w ostatnich czasach modernizowane dwukrotnie, dopuszcza stwierdzenie nieważności, skutkiem czego powstają rodziny hybrydowe, posiadające dzieci z pierwszego (tego „nieważnie” zawartego) i drugiego małżeństwa. W przeszłości zresztą ponowne związki zawierane po śmierci współmałżonka również tworzyły rodziny hybrydowe, gdy

\footnotetext{
1 Zob. T. Piwowarski, Rodzina jako społeczność naturalna wg. św. Tomasza z Akwinu, „Roczniki Filozoficzne” 8 (1960), z. 2, s. 89-111.

2 S. Kawula, Diagnozowanie potrzeb opiekuńczo-wychowawczych środowiska rodzinnego, Toruń 1978, s. 125.

3 R. Doniec, Rodzina wielkiego miasta. Przemiany społeczno-moralne $w$ świadomości trzech pokoleń, Kraków 2001, s. 11.
} 
rodzic - wdowiec - wchodził w nowe relacje i na świat przychodziły dzieci różnych matek bądź ojców.

\section{Czym jest rodzina?}

Wielość definicji, określeń i przepisów prawnych ukazuje różnorodność myślenia o rodzinie; nieco inaczej określa ją prawo, opierając się na związku małżeńskim, a inaczej obyczaj czy nowe wzorce zaczerpnięte z innych kultur.

W świetle prawa kanonicznego małżeństwo rozumie się jako trwały, dozgonny związek, „przymierze małżeńskie, przez które mężczyzna i kobieta tworzą ze sobą wspólnotę całego życia, skierowaną ze swej natury do dobra małżonków oraz do zrodzenia i wychowania potomstwa"4.

Przykłady definiowania rodziny można by mnożyć. Anna Kwak stwierdza, że „powszechnie przez rodzinę uważa się parę małżeńską i jej dzieci. Członkowie rodziny zazwyczaj mieszkają razem i tworzą jedno gospodarstwo domowe" "Takie podejście zawęża rodzinę do grupy osób, które łączą stosunki małżeńskie i rodzicielskie.

Rodziny wielopokoleniowe (mieszkające pod jednym dachem) należą już do przeszłości, szczególnie w przestrzeni wielkich miast. Dziś zazwyczaj członkowie rodzin spotykają się rzadko albo wcale, ze względu na zaabsorbowanie pracą czy też z racji zamieszkiwania w znacznym oddaleniu, itp.

Wobec ogromu materiału opisującego przemiany dotyczące rodziny zdecydowano się poruszyć tylko niektóre problemy związane z przemianami społecznymi, kulturowymi, strukturalnymi. Najistotniejsze są te, które mają wpływ na kształtowanie się modelu rodziny, a zatem także na wychowanie młodego, nowego pokolenia.

Przez setki tysięcy lat rodzina stanowiła źródło edukacji i ostoję bezpieczeństwa jej członków. To ona była pierwszym i najważniejszym środowiskiem socjalizującym i to w niej przekazywano wartości oraz normy moralne. Obecnie jej funkcje przejęło państwo. Dziś mamy do czynienia z rozluźnieniem więzów rodzinnych, determinacją zachowań, determinacją społeczną.

\footnotetext{
$4 \quad$ E. Sztafrowski, Podręcznik prawa kanonicznego, t. 4, Warszawa 1986, s. 7; KPK kan. 1055 par. 1.

5 A. Kwak, Rodzina i jej przemiany, Warszawa 1994, s. 9.
} 
Tym, co spaja rodzinę, powinna być miłość. To nie tylko emocje i uczucia, to także niematerialny kapitał, który pozwala funkcjonować i przetrwać także w trudnych chwilach. Nie jest ona wartością autoteliczną, lecz wchodzi w relacje z innymi wartościami, np. z nadzieją. Odnosi się do dalszej lub bliższej przyszłości, nadaje wymiar, wymaga cierpliwości, ale też samotności, pozwala ukazywać kierunek w walce ze słabościami, stawać się lepszym, pracować z przekonaniem. Miłość ma swój porządek: ofiarność, dzielność, szacunek.

\section{Przemiany zachodzące XXI wieku}

Spojrzenie na rzeczywistość z dystansu, sentymentalne związki z miejscami, tradycją, klimatem w rodzinie i wokół rodziny - to wspomnienia starszego pokolenia. W młodszym pokoleniu obserwuje się zmiany zarówno w samej strukturze rodziny, jak i pełnionych rolach i zadaniach. Wśród młodych widoczne są zmiany zasad, norm, manier, słownictwa, a i prawda jak gdyby traci na znaczeniu, zyskują natomiast marketing, konsumpcjonizm.

Zarówno struktura, jak i styl życia rodziny przez stulecia ulegały przemianom, nigdy jednak w takim tempie i tak głęboko, jak w ostatnich 20-30 latach. Przeglądając teksty literackie, zdjęcia, pamiętniki, obrazy, możemy łatwo odnaleźć różnice w słownictwie, ubiorze, wyglądzie, pozycji społecznej ówczesnych i współczesnych ludzi. Wszystkie one są wyrazem zmieniającego się zarówno stylu życia, jak i funkcji rodziny. Czas wszystko przekształca, epoka analogowa odchodzi w zapomnienie, rozkwita ta cyfrowa i to ona ma duże znaczenie nie tylko dla komunikacji interpersonalnej, pracy, szkolnictwa, ale także odciska swoje głębokie znamię w percepcji i życiu rodziny. Żyjemy w zaawansowanym ekonomicznie, technologicznie i społecznie świecie zdalnego komunikowania.

Internet, w tym Instagram i Facebook - to jest „kontynent”, na którym żyją ludzie młodzi, którym niekiedy trudno dostrzec, że życie kontynuuje się w realu. Muszą oni jednak pamiętać, że rodzina, jakakolwiek by nie była, pozostaje dla każdego jej członka (szczególnie dziecka) modelem, wzorcem informującym o zasadach, wartościach, sposobie życia, itp. Każda rodzina skrywa w sobie szereg możliwości. 


\section{Przemiany - rzeczywistość wielotwarzowa}

Dostępność edukacji sprzyja wykształceniu młodzieży, bez względu na płeć i miejsce zamieszkania. Praca zawodowa zaś dała kobietom niezależność ekonomiczną, zapewniła satysfakcję zawodową, pozornie odciążyła od prac i obowiązków domowych. W gospodarstwach domowych pojawia się coraz więcej sprzętu mechanicznego, popularne są też zakupy przez internet. Wychowawcza funkcja rodziny w znacznym stopniu realizowana jest zaś poprzez instytucje pozarodzinne: żłobek, przedszkole, szkołę, zajęcia pozalekcyjne, ośrodki wychowawcze itp. Czas przebywania, „wychowywania” dziecka w rodzinie znacznie się skurczył. Otwarte granice, podróże, nowe technologie umożliwiają poznanie innych krajów, znacznie lepsza jest też sytuacja materialna rodzin niż jeszcze 30 lat temu, co daje możliwość poruszania się nie tylko w obrębie własnego kraju. Poznawanie różnorodnych kultur poszerzyło horyzonty i stworzyło możliwość oraz wyzwoliło chęć realizowania się poza rodziną, na co niewątpliwie miał też wpływ rozwój nauki i postęp techniczny. Założenie rodziny przestało być dla wielu priorytetem, dlatego opóźnił się wiek zawierania małżeństw i rodzenia dzieci, co jednak nie oznacza, że nastąpiła rezygnacja z życia małżeńskiego.

Zmiany zewnętrze obejmują wielowymiarową rzeczywistość. To nie tylko nowe hasła i zasady (rozumiane często jako brak zasad). Kluczową rolę odegrały edukacja i praca zawodowa kobiet, ale także wzorce medialne, zmiany relacjach $\mathrm{w}$ rodzinie, rozpad rodzin wielopokoleniowych. Hierarchiczność zamieniono na partnerstwo.

\section{Nowe formy życia małżeńskiego i rodzinnego}

Nie ulega kwestii, że rodzina polska przestała być stałym i trwałym układem organizacyjnym. Obok rodzin monoparentalnych pojawiają się coraz liczniej alternatywne formy życia małżeńskiego i rodzinnego. Tomasz Szlendak podkreśla, że rodzina nie jest już w naszym kręgu kulturowym tożsama z małżeństwem. Rodzina „to co najmniej jedna diada rodzic (dorosły opiekun) - i dziecko". Szendlak nie zgadza się, aby rodzina obejmowała diady, 
w których brakuje dziecka. Mianem „niby-rodziny” określa singli, związki typu DINKs (Double Income No Kids), układy sieciowe seniorów ${ }^{6}$.

Wydawać by się mogło, że rodziny mają te same potrzeby podstawowe, jednak inaczej je realizują. Jako system tworzą one sieć podsystemów i współzależnych powiązań. Żadna rodzina nie jest kopią innej, bowiem tworzą ją niepowtarzalne osobowości, z różnymi wizjami nie tylko rodziny, ale także celów życia i sposobów jego realizacji. Wszystkie one, pomimo dostępności wielu urządzeń technicznych, ułatwiających codzienne życie, odczuwają też brak czasu i nadmiar obowiązków.

Zdążamy nie tyle do zmiany modelu rodziny, bo jest on ściśle powiązany ze zamianami kulturowymi, religijnymi, ile do uznania różnych form życia rodzinnego. Jeszcze w XX wieku dziewczyna z dzieckiem (samotna matka) była źle postrzegana, a dzisiaj samotne macierzyństwo $\mathrm{z}$ wyboru, jako decyzja kobiety, jest akceptowane, by nie powiedzieć - preferowane. Obserwuje się także bardzo niebezpieczne zjawisko, jakim jest zaniedbywania obowiązków rodzicielskich, stosowanie przemocy w stosunku do dzieci, o czym donosi codzienna praca lekarzy. Coraz częściej zdarzają się rodziny dysfunkcyjne, niewydolne wychowawczo, dzieci zaniedbane. Wzrasta liczba rodzin zastępczych i dzieci objętych różnymi formami opieki pozarodzinnej, co wskazuje na „jakość” rodziny.

Zarówno rodziny formalne, jak i te nieformalne, pełne i niepełne, prawidłowo funkcjonujące, wydolne wychowawczo i ekonomicznie, nie zwracają na siebie uwagi. Natomiast rodziny niewydolne, dysfunkcyjne czy wręcz patologiczne ${ }^{7}$ stają w centrum zainteresowania mediów, tworząc obraz nieprecyzyjny czy wręcz fałszywy obraz rodziny współczesnej.

Zaangażowanie religijne ma istotny wpływ na życie rodziny, ale jest tez odwrotnie - to rodzina ma wpływ na zaangażowanie religijne, które ewidentnie maleje w młodym pokoleniu. W przyszłości będą funkcjonować rodziny o różnym statusie prawnym, oparte na związkach małżeńskich sakramentalnych lub cywilnych, związkach partnerskich i wolnych. Ponieważ rodzina pochodzi od słowa „rodzić”, warto zwrócić uwagę, że

\footnotetext{
T. Szlendak, Socjologia rodziny. Ewolucja, historia, zróżnicowanie, Warszawa 2010, s. 113.

Szerzej na ten temat: T. Olearczyk, Sieroctwo i osamotnienie. Pedagogiczne problemy kryzysu współczesnej rodziny, Kraków 2007; T. Olearczyk, Rodzina między starym a nowym paradygmatem, Rużemberok 2013; Współczesne uwarunkowania procesu wychowawczego, w: Rodzina i edukacja w zmaganiu o przyszłość Europy, red. E. Osewska, Tarnów 2016, s. $129-148$.
} 
prawdopodobnie zwiększy się liczba samotnych matek niepozostających w żadnym związku, ale samodzielnie wychowujących dziecko i ukrywających tożsamość ojca dziecka. Już teraz trwałość związku przestaje być obowiązującą zasadą, a miłość ma konkurentkę - pieniądze. Ekonomia zaczyna odgrywać znaczącą rolę, a w konsekwencji zmianie ulega też system wartości. Bardzo widoczna jest transformacja w sferze normatywno-aksjologicznej nowoczesnego społeczeństwa, a model małżeństwa i rodziny prezentowany przez media znacznie odbiega od tradycyjnego. Nie ma powrotu do przeszłości, można więc domniemywać, że w przyszłości funkcjonować będą co najmniej dwa takie modele: 1) oparty na tradycyjnych wartościach i związku sakramentalnym, 2) oparty na uczuciach, emocjach, a także związek zawierany na określony czas i na obowiązujących umownych zasadach. Wydaje się, że przepisy prawne winny precyzyjnie określać rodzaj związku małżeńskiego i rodzinnego.

Przemiany dokonują się zarówno w wymiarze strukturalnym, kulturowym, społecznym, jak i demograficznym, zaś alternatywne formy życia rodzinnego mają związek z wychowaniem i zachowaniem młodego pokolenia. Na poczucie szczęścia małżeńskiego wpływają nie tylko wartości, ale też wzajemne oczekiwania. Zgodność oczekiwań i wartości zwiększają zaś wzajemne zadowolenie z małżeństwa.

$\mathrm{Na}$ gruncie pedagogiki analizowane są najczęściej zagadnienia akcentujące rolę matki. Niewielu autorów podjęło wysiłek rozpoznania kwestii związanych $\mathrm{z}$ wychowaniem potomstwa $\mathrm{w}$ rodzinie o nowych konfiguracjach, w których np. jedna kobieta jest matką kilkorga dzieci mających różnych ojców. W literaturze przedmiotu nie dostrzega się problemu ojcostwa rozproszonego ${ }^{8}$ i ojcostwa bezdomnych, które ma swoją specyfikę, rodzi określone skutki wzorcotwórcze, społeczne i wychowawcze.

W rodzinie kształtuje się także świadomość narodu. Dojrzewanie osobowe człowieka dokonuje się poprzez kulturę, dzięki której naród staje się wspólnotą kulturową ${ }^{9}$. Dom stał się otwarty w inny sposób, co wyraża się już nie przyjmowaniem gości, sąsiadów, ale nieustanną obecnością innego (poprzez medium internetu). Zmianie uległy też relacje między małżonkami

$8 \quad$ Zob. szerzej: T. Olearczyk, Rodzina miedzy starym a nowym paradygmatem, Rużemberok 2013, s. 150-154.

9 Zob. K. Czuba, Idea Europy kultur w nauczaniu Jana Pawła II, Warszawa 2003, s. $88-101$. 
- nie ma rodzin patriarchalnych, są partnerskie, a czasem patchworkowe, co także stwarza nowe, nieistniejące wcześniej warunki wychowawcze dla dzieci. Pojawiły się też trudności wynikające z niewypełniania obowiązków rodzicielskich $\mathrm{w}$ rodzinie.

\section{Dynamika przemian rodziny - pokolenie bez wychowania}

Dzięki nowym technologiom rzeczywistość realna miesza się z wirtualną, zmieniając nasz sposób myślenia, styl życia, obyczaje i oblicze świata. Oddziałuje ona także na przyszłość rodziny. Małżeństwo i rodzina zmieniają swoje znaczenie, a młodzi ludzie w procesie socjalizacji nabywają przekonań „wolnościowych”. Życie staje się coraz bardziej wygodne, dzięki rozwojowi techniki i poprawy zasobności społeczeństwa, a równocześnie zanika poczucie wstydu i grzechu, niemodne staje się poświęcenie (słowo dziś nieużywane). Można odnieść wrażenie, że rodzice chcą mieć dziecko jako dodatek do kariery, ale niekoniecznie chcą się całkowicie angażować w jego wychowanie, chętnie oddają pod opiekę osób lub instytucji, co ogranicza czas kontaktu osobistego i wpływ wychowawczy rodziców. Ma to znaczenie dla budowania więzi emocjonalnych i rozwoju emocjonalnego dziecka. Wartości chrześcijańskie, tak chętnie deklarowane, nie znajdują potwierdzenia w praktyce życia rodziny i społeczeństwa. Pomimo prowadzonej od lat katechezy w szkole nastąpiło „zeświecczenie”, osłabienie życia religijnego, a także podważanie czy wręcz zanik autorytetów.

Filarem wychowania jest jakość kontaktów, relacji osobowych między małżonkami - rodzicami - i w relacji rodzice-dzieci. Trzeba podkreślić, że nie każda komunikacja jest relacją, ale każda relacja - jest komunikacją. Chodzi o nawiązanie relacji z dzieckiem, $\mathrm{z}$ uczniem, $\mathrm{z}$ rodzicem. $\mathrm{W}$ rodzinach zabrakło hierarchizacji, relacje pomiędzy pokoleniem rodziców i dzieci stały się bezpośrednie, braterskie, by nie powiedzieć, że czasem koleżeńskie. Zmniejszył się dystans między dzieckiem a dorosłym, nastąpiło „skrócenie” dzieciństwa (coraz wcześniej dzieci „wchodzą" w rolę dorosłych).

Idee antypedagogiki brzmiały: „Dzieci nie potrzebują wychowania! Kto kocha, ten ich nie wychowuje!”. Antypedagogiczna postawa Alice Miller 
skierowana była nie przeciwko wybranej metodzie, lecz przeciwko wychowaniu w ogóle. Jej zdaniem to nie dzieci potrzebują wychowania, lecz dorośli (co jest prawdą teraz, kiedy dorosło pokolenie niewychowanych rodziców). Warto zauważyć, że wolność niesie też wymagania. Brak cnót w wychowaniu prowadzi do próżni moralnej, często trudności w znalezieniu właściwej drogi w życiu, nieraz przyczynia się do zaburzeń zdrowotnych, a także zaburzeń psychicznych. Lansuje się dziś wychowanie bez wychowania, „bezstresowe” (bez wychowawców, gdyż „niewychowany wychować nie potrafi”, brak zasad, wymagań, liberalizm wychowawczy).

Dziś każdy jest sobie sterem, żeglarzem, okrętem. Podstawowe zagrożenie dla wychowania stanowi brak wychowania, brak zasad i dobrych wychowawców, nieuznawanie autorytetów, przykład „osobowości” medialnych, celebrytów. Niebezpieczne jest też lekceważenie lub pomijanie trójwymiarowości człowieka, jego strony psychofizycznej, moralnej i duchowej.

Liberalizm wychowawczy nie dostrzega skutków nie tylko zachowania, ile wewnętrznej dewastacji młodego człowieka. A przecież człowiek to nie tylko ciało (nadmiernie dzisiaj eksponowane), ale też cała sfera moralno-duchowa, która odgrywa zasadniczą, kluczową rolę w wychowaniu, w kształtowaniu człowieka.

Stosowanie kamer w szkołach oraz miejscach pobytu dzieci i młodzieży nie jest wychowaniem ${ }^{10}$ - kamera jest tylko narzędziem, i to kiepskim. Wychowanie odbywa się w relacjach osobowych, tymczasem w obecności kamery nauczyciel czuje się $\mathrm{w}$ pewnym sensie zwolniony z podejmowania działań, gdyż narzędzie to "nadzoruje” i zapisuje zachowania uczniów. W wychowaniu niezwykle ważny i niezbędny jest kontakt osobowy, dialog, obecność nauczyciela, który wychodzi ze słowem do uczniów. W trwającym procesie wychowania winne następować przemiana wewnętrzna, przyswojenie norm i zasad, socjalizacja i samosterowność w zachowaniu. Nie kradnę, bo to jest złe, nie akceptuję takiego zachowania, nie dlatego, że kamera „podgląda”, rejestruje. Uczciwości nie można nauczyć za pomocą narzędzi, a wychowanie musi być oparte na wartościach i obowiązujących czytelnych zasadach.

10 Cisza w teorii i praktyce. Obraz interdyscyplinarny, red. T. Olearczyk, Kraków 2014 s. $8-9$. 


\section{Problemy wychowawcze, z jakimi boryka się współczesna rodzina}

Młodzież ma dziś coraz więcej praw, przyjemności, coraz mniej obowiązków, odpowiedzialności za działanie, wzajemnych powinności - a przecież nie na tym polega kształtowanie młodego człowieka. W takim świecie każdy musi mieć najlepszy, najważniejsze są pochwały i nagrody, najwyższe oceny, a przecież życie nie wystawia ocen, tylko przynosi „schody”, po których trzeba wchodzić coraz wyżej, w trudzie i znoju. Należy uświadamiać młodych, że w życiu są trudności, które muszą oni rozwiązywać, pokonywać je. Kiedyś w wychowaniu bardzo pomocne było harcerstwo, hartowanie duchowe, kształtujące wytrwałość, dzielność. Tymczasem obecnie zabrakło w nim cnót, jest za to zbyt dużo swobody w myśl zasady: „wszystko mi wolno”, „nam się należy”. W chaosie codzienności gdzieś zapodziały się odwaga cywilna, honor, godność, dzielność.

Prawda, że obecnie nie ma skąd brać wzorów, jest przykra. „Czego się Jaś nie nauczy, Jan nie będzie umiał”, „jaka mać, taka nać”, „niedaleko pada jabłko od jabłoni” - przysłowia wskazują na znaczenie rodziny i jej wzór wychowawczy. Rozwój jest wspinaczką z trudem, jest wyrzeczeniem, wysiłkiem, dyscypliną, ale to wszystko przekłada się na radość z efektów.

Trzeba zwrócić uwagę na to, że poszerzył się również zakres słownictwa, ale nie tego literackiego, pięknego, lecz wulgaryzmów i skrótów myślowych. Potrzeba zatem nobilitacji słowa i milczenia. Bez milczenia, namysłu, wypowiadane słowa nie mają sensu. Demokrację trzeba budować na wartościach, zaś wychowanie dzieci na mądrej, rozumnej miłości i obecności. Pokolenie wychowywane w atmosferze indoktrynacji, podsłuchu przestaje obowiązywać kultura, młodzi żyją w świecie równoległym do rzeczywistego. Zdalne wychowanie i zdalna miłość przynoszą ten sam katastrofalny efekt - młodzież lepiej kontaktuje się z wirtualnym światem niż z rodzicami i dorosłymi.

Warunkiem wychowania jest przetwarzanie myśli w słowa, w ruch. Należy skupić się na działaniu, np. na danej myśli, zachowaniu. W szybko zmieniającym się świecie, zdominowanym przez nowoczesne technologie, problemem będzie umiejętność koncentracji, czyli praca z własnym umysłem i sumieniem. Świat dorosłych psuje i gorszy młodzież, a potem ma do niej pretensje. Pozostaje pytanie, od kogo zatem młodzi mają się nauczyć pracy nad sobą. 


\section{Wychowanie w nowej rzeczywistości}

Wejście do Unii Europejskiej spowodowało zwiększenie mobilności społeczeństwa. „Religia” panująca wykuwa się w „krzemowej dolinie” - najbardziej ceniona jest wiedza. Należy jednak dodać, że technicyzacja myślenia o życiu, podejście mechanistyczne, oddzielność inteligencji od sumienia, od świadomości są zabiegiem ryzykownym.

Wychowanie młodego pokolenia przebiega $\mathrm{w}$ innej rzeczywistości niż jego rodziców i dziadków. Proces ten wciąż pozostaje jednak zadaniem rodziny, dzielonym ze szkołą, a także coraz liczniejszymi instytucjami opiekuńczymi i wychowawczymi (co świadczy o słabości i niewydolności rodziny) ${ }^{11}$.

Istotnym elementem jest realizowany $\mathrm{w}$ rodzinie proces wychowawczy, w którym przekazuje się system wartości. Jest to miejsce, w którym „uczymy się istnieć" ${ }^{12}$. Budowanie silnej jednostki, która ma utrwalony system wartości i kieruje się normami społecznymi, jest jednym z nadrzędnych elementów wychowania. Ponadto istotne jest, by w młodym człowieku implementować poczucie wartości wyższych i motywacji.

Rodzina jest nie tylko depozytariuszem współczesnych zjawisk społecznych, ale stanowi także swoistego rodzaju lustro zmian, w którym widać, czy idą one $\mathrm{w}$ dobrym kierunku. Wychowanie to skomplikowana praca z dzieckiem, na co wpływają deficyty fragmentaryczne, zaburzenia, dysfunkcje, problemy rodzinne, traumy domowe. Proces ten łączy w sobie elementy fizyczne, psychiczne, duchowe, emocjonalne, tworząc niepowtarzalną jakość osoby ludzkiej, która poddana jest w sposób świadomy i zamierzony bądź mimowolny wielu różnym oddziaływaniom wewnętrznym i bodźcom zewnętrznym.

Określenie „wychowanie”, sama konstrukcja tego słowa, nasuwa możliwość dokonania analizy jego rozumienia. "Wy-” - (przedrostek osobowy) dotyczy "ja"; „-chowanie" ma dwa znaczenia. Jedno wskazuje na "chowanie” czegoś, co trzeba „odkryć” i można „wydobyć"; drugie oznacza „chów” i dotyczy strony fizycznej, cielesnej.

Należy też zwrócić uwagę na problem samotności dziecka. Gdy rodzice są zajęci, żyją obok siebie, wiele godzin spędzają w pracy, a dzieci w szkole i na zajęciach pozaszkolnych, młodym ludziom pozostaje poszukiwanie zmiany.

11 A. Giddens, Konsekwencje nowoczesności, tłum. E. Klekot, Kraków 2008, s. 30-31.

12 Jan Paweł II, Homilia podczas mszy św., Maastricht, 14 maja 1985 r. 
Kuszące okazują się atrakcyjność i „akcyjność” ulicy albo Internet, w którym wystarczy kliknięcie, by wejść w świat wirtualny, zawsze obecny, dający złudne poczucie wolności i anonimowości, kontakt $\mathrm{z}$ grupą. W wychowaniu kluczową rolę odgrywa relacja pedagogiczna, „emocjonalny stosunek” dojrzałego człowieka (ojca, matki) do osoby stającej się dojrzałym człowiekiem.

\section{Kondycja współczesnej rodziny}

$\mathrm{Na}$ rodzinę wpływają zarówno bieżące warunki, jak i to, co miało miejsce w przeszłości. Przemiany dokonujące się w XX i XXI wieku zainicjowały nie tylko laicyzację życia społecznego, a przede wszystkim rodzinnego, ale także hedonistyczną formę funkcjonowania w rzeczywistości społecznej. Chęć czerpania z życia jak najwięcej stała się motorem indywidualizacji jednostek. Obecnie stanowi ona nie tylko styl życia pojedynczych osób, ale także motto wielu dzisiejszych związków małżeńskich i rodzin, w myśl zasady, by mieć jak najwięcej.

Można stwierdzić, że potrzeby dzisiejszych rodzin są większe i poszerzają się na przestrzeni lat, w miarę wzrostu świadomości społecznej, zwiększenia mobilności i dostępu do kolejnych dóbr materialnych. Najistotniejsze przemiany dotyczą roli oraz funkcji ojca i typowego dla patriarchatu autorytetu ojca i męża. Obserwujemy wzrost wolnych relacji i kontaktów seksualnych. Gloryfikacja dobra jednostki i poszukiwanie przyjemności przyczyniły się do braku spójności rodzin. Ma na to wpływ również medialne promowanie wzorów rodziny. Tempo zmian, których jesteśmy świadkami, stale wzrasta. „Mamy poczucie nietrwałości, przelotności zdarzeń, co znajduje odbicie w naszej świadomości i w sposób znaczący zmienia nasz stosunek do innych ludzi, do rzeczy, do całego otaczającego nas świata idei, sztuki i wszelkich wartości"13.

Jakość życia współczesnej rodziny znacznie odbiega od tej „tradycyjnej”. W dość szybkim tempie nastąpiła bowiem komercjalizacja życia rodzinnego - widoczne są dominanta pieniądza, zachwyt konsumpcją, kapitałem, a także konsumowanie relacji, przyjaźni, dążenie do przyjemności, obfitości, luksusu. Zmienił się kontekst kulturowo-społeczno-ekonomiczno-wychowawczy

13 A. Toffler, Szok przyszłości, Poznań 1998, s. 27. 
- coraz częściej dominuje wzór rodzica rozwiedzionego, funkcjonującego w różnych związkach czy konfiguracjach. Brakuje umiejętności, a czasem chęci rozwiązywania problemów w małżeństwie, rodzinie, przez co łatwo o jej rozpad. Małżeństwo postrzegane bywa jako ograniczenie praw i wolności, porażka wyboru. Nastąpiła zmiana ról i hierarchii w rodzinie, unifikacja, „równopartnerstwo”, coś w rodzaju braterstwa.

Zmieniają się też system wartości oraz obraz kobiety i mężczyzny, a także ich role rodzinne, zawodowe i społeczne. Mamy do czynienia z pokoleniem, dla którego priorytetem jest rozwój zawodowy. Pewną wygodą stają się nieposiadanie dzieci albo późne pierwsze macierzyństwo.

Należy też zwrócić uwagę na kryzys męskości, który jest wynikiem kryzysu wartości, wiąże się także ze zmianą ról w rodzinie. Znacznie bardziej zauważalny jest on w miastach. Profesor Zimbardo ${ }^{14}$ stwierdza, że mężczyźni chętnie sięgają np. po gry, by uciec od trudów codzienności, odchodzą od męskich wzorców. Rozpoznają u siebie wrażliwość, która jest trendem promowanym, widocznym w kulturze pop. Porozbijane rodziny nuklearne, samotnie wychowujące matki, samotni ojcowie, nie mają skąd czerpać wzorców, tymczasem życia uczymy się z obserwacji. Zimbardo proponuje więc, by uczyć chłopców męskich zachowań.

Maskulinizacja zachowań kobiecych i zmiana ról skutkują tym, że wyrosło pokolenie kobiet wyedukowanych, ambitnych, chcących niezależności, pragnących wykorzystać swoje wykształcenie i umiejętności. Pokolenie to nie chce już zostać w domu (stąd potrzeba żłobków, przedszkoli). Na zmianę postaw i zachowań kobiet wpłynęły wojna, emigracje, emancypacja, a także pojawienie się na rynku pracy korporacji. Kobieta traci swoje terytorium, na którym żyła do tej pory. Praca rodziców, żłobek, przedszkole czy szkoła wyznaczają rytm życia rodziny. Zmieniają się tradycyjne role, feminizm „wyzwolił” w kobiecie aktywne życie poza rodziną. Konieczne jest ustalenie nowych ról, choć „scenografia” życia podlega nieustającym zmianom. Kryzys rodziny może jednak stać się szansą, by szukać mądrego rozwiązania. Teraz, kiedy koronawirus zatrzymał rodziców w domu, zaczynają oni poznawać siebie wzajemnie.

Rodziny zwiększają swoje umiejętności w zakresie adaptowania się do szybkich zmian społecznych. Również u dzieci dostrzec można większą swobodę manifestacji swojej odrębności i suwerenności, a także swobodę

14 R. J. Gerrig, P. Zimbardo, Psychologia i życie, Warszawa 2020. 
o podłożu emocjonalnym i seksualnym. Kolejnym bardzo niepokojącym sygnałem w odniesieniu do prawidłowego funkcjonowania rodziny są rozwody. W sensie formalnym rozwód jest kategorią prawną. W sensie socjologicznym stanowi wskaźnik rozpadu rodziny, a w sensie pedagogicznym generuje pewne trudności wychowawcze. Praca obojga rodziców wymaga dokonania bilansu czasu poświęconego rodzinie i dziecku.

\section{Trudności w pełnieniu ról rodzinnych}

Nieobecność rodziców w domu spowodowana obowiązkami zawodowymi, zaangażowanie w pracę, konieczność podnoszenia kwalifikacji, czasem też miłość na odległość, nie tylko zagrażają stałości małżeństwa, ale ograniczają też możliwości poznawania dziecka i towarzyszenia mu w procesie wzrostu i rozwoju. Żadna miłość nie lubi odległości. Nieobecność powoduje zachwianie równowagi psychicznej i moralnej oraz znaczne trudności w stosunkach rodzinnych.

Utrzymanie trwałości małżeństwa jest trudne w czasach, w których wszystko jest płynne, wielowymiarowe, rozmyte, tymczasowe. Małżeństwo traktuje się jako zespół obowiązków, skarg i zażaleń - tymczasem miłość wymaga pracy nad sobą, co jest najtrudniejsze.

Następuje też zmiana postaw wobec rodzicielstwa - dziecko jest traktowane jako dopełnienie siebie. Ludzie często chcą mieć dziecko, ale wychowanie powierzają innym, tłumacząc, że taka jest konieczność, że to służy jego lepszemu rozwojowi. Od wychowania ważniejsza jest samorealizacja kobiet poza domem. Obserwujemy dominację kobiecości nad macierzyństwem (co przejawia się w dbałości o idealne ciało, cesarskim cięciu na żądanie), a praca stawiana jest przed rodziną.

\section{Kult pracy a życie rodzinne}

Lata 90. zmieniły naszą świadomość. Dla wielu ludzi (w znacznej mierze dotyczy to młodego pokolenia) rozwój zawodowy stał się jedynym sensem 
życia, to z pracy (najczęściej w korporacji) czerpią oni całą satysfakcję, zajmuje im ona zdecydowaną większość dnia. Często ludzie ci poza pracą nie podejmują żadnej innej aktywności, może z wyjątkiem dbania o ciało w formie uczęszczania na basen czy siłownię, lecz tylko po to, by jeszcze lepiej pracować. Praca daje spełnienie, zadowolenie, ludzie są szczęśliwi, że pracują i są rozpoznawalni. Niezauważalny upływ czasu powoduje, że w pewnym momencie ich życia jest za późno na zbudowanie rodziny.

Nie chciałabym generalizować postaw wobec pracy, nadmiernego zaangażowania, może to bowiem zależeć od indywidualnych sytuacji. Zatrudnienie w korporacjach, mediach, znanych firmach zagranicznych nobilituje, zapewnia dobre zarobki, ale ogranicza kontakty towarzyskie tylko do tych zawodowych, w efekcie praca zastępuje więzi rodzinne. W wielogodzinną pracę najbardziej angażują się młodzi, którym w rezultacie nie wystarcza czasu na ułożenie sobie życia osobistego.

Jeśli udaje się $\mathrm{w}$ końcu założyć rodzinę, rozpada się ona $\mathrm{z}$ powodu nieobecności rodziców spowodowanej nadmiernym zaangażowaniem w pracę. $Z$ tej też przyczyny młodzi często w ogóle nie zakładają rodzin, świadomi swojej sytuacji, wolą żyć bez zobowiązań. Sytuację może zmienić rodzicielstwo (często pozamałżeńskie). Pojawienie się dziecka zmienia perspektywę, uzasadnia sens życia. Na problem nadmiernej pracy można oczywiście spojrzeć też z innej strony - wiele osób dużo pracuje, bo taki jest przymus ekonomiczny.

W tym kontekście pojawiają się pytania o to, czy i w jakim zakresie dynamiczne przemiany struktury i sposobu funkcjonowania rodziny wpływają na proces wychowania. W jaki sposób dezorganizacja życia rodziny wpływa na wychowanie? Czy dziecko to podmiot pożądania czy przedmiot wychowania - czy konsument? Jaki jest związek pomiędzy trwałością rodziny a wychowaniem?

\section{Czynniki dezintegrujące rodzinę}

Rodzina wyznacza aspiracje i dążenia człowieka, określa wzory i wartości, do których należy dążyć. Człowiek dorosły, „programowany” w rodzinie macierzystej, powielał "kalkę pokoleniową" - rodzina miała rolę wzorcotwórczą. 
Dziś można z całą pewnością stwierdzić, że na członków rodziny, zarówno dzieci, jak i dorosłych, wpływają zarówno atmosfera rodzinna, jak i czas, w którym żyjemy, a także wspólnie spędzany czas i obecność rodziców. Niestety w „formowaniu”, wychowaniu człowieka coraz mniejszy jest udział rodziny pochodzenia, a coraz większy wpływ mediów.

Stabilność rodziny tradycyjnej wynikała z przysięgi: „Nie opuszczę Cię aż do śmierci”, co zawarte jest też w przysłowiu: „Śmierć i żona od Boga przeznaczona”. Ważna była świadomość sakramentu. Pierwszą grupą trudności zauważonych przez papieża Franciszka są te wynikające ze sposobu życia rodzin we współczesnym świecie. Człowiek odrzuca to, co nie jest już przydatne lub satysfakcjonujące, i przestawia się na konsumowanie relacji, przyjaźni czy religii ${ }^{15}$ oraz dążenie do przyjemności, obfitości, luksusu. Drugim problemem jest desakralizacja życia małżeńskiego.

Kryzysy społeczne i cywilizacyjne odzwierciedlają się w przeobrażeniach, jakie dokonują się w obrębie warunków i stylów życia rodzin. Dlatego większość sytuacji, które pedagogika postrzega jako zjawiska niepożądane społecznie lub wręcz szkodliwe, ma swoje źródła w nieprawidłowym, zakłóconym funkcjonowaniu rodziny, w jej okresowych problemach, kryzysach i zagrożeniach. Trudno jest przedstawić wyczerpującą klasyfikację zagrożeń współczesnej rodziny. Wielu autorów podaje własne typologie źródeł zła, które w znacznym stopniu różnią się w ocenie ich znaczenia, a także w interpretacji przyczyn dezorganizacji rodziny.

Istnieje jeszcze jeden problem - wprawdzie marginalny, ale wart zauważenia. To „in vitro” (sztuczne zapłodnienie, które dzieli się na homologiczne - gdy gamety pochodzą od małżonków, oraz heterologiczne - kiedy przynajmniej jedna z komórek płciowych pochodzi od dawcy różnego od obcego dawcy). Dziecko nie jest genetycznie potomkiem swoich rodziców (przynajmniej jednego z nich), lecz anonimowych dawców komórek. W skrajnych przypadkach może ono nie mieć żadnej więzi biologicznej z prawnymi rodzicami. „Czyim jestem dzieckiem - pyta po latach - rodziców, którzy mnie wychowali, czy też tych, od których otrzymałem materiał genetyczny?”. Zapłodnienie heterologiczne powoduje także rozdźwięk między pokrewieństwem genetycznym a pokrewieństwem społecznym.

15 Franciszek, Dar odnowionej bliskości między rodziną a Kościołem, „L'Osservatore Romano” 10 (2015) wyd. pol., s. 48-49. 
Problem jest znacznie głębszy, gdy dziecko ma pięcioro rodziców ${ }^{16}$ : dwoje genetycznych (dawcy komórek żeńskiej i męskiej), matkę surogatka (która nosi i rodzi dziecko $\mathrm{z}$ in vitro) i dwoje rodziców prawnych (dla których to dziecko jest „przygotowywane”).

Kształt i funkcjonowanie rodziny w istotny sposób zależy od „reszty” świata społecznego, zewnętrznego $\mathrm{w}$ stosunku do rodziny. Społeczeństwo globalne (wraz z zawartymi w nim zhierarchizowanymi układami społecznymi) wpływa na rodzinę, odpowiednio modyfikując jej strukturę, funkcjonowanie, $z$ kolei modyfikowana rodzina ma wpływ na globalne społeczeństwo, jego procesy i substruktury. Jeśli społeczeństwo podlega intensywnym przeobrażeniom, jego wpływ na rodzinę jest tym większy, i ulega ona wyraźniejszym modyfikacjom, zwiększając swój zakres oraz siłę oddziaływania na społeczeństwo globalne.

Analizując procesy, jakim podlega współczesna rodzina (z autopsji oraz rodzin przyjaciół i znajomych), skłonna jestem przyjąć za Tadeuszem Pilchem dwie podstawowe orientacje. Pewne uproszczenie, którym są one obarczone, wpływa jednak na obrazowy i klarowny sposób przedstawienia zagrożeń oraz przejawów dysfunkcyjności współczesnej rodziny.

Pierwszych przemian w rodzinie można doszukiwać się w przemianach cywilizacyjnych (zapoczątkowanych w XIX wieku i szybko postępujących współcześnie w cywilizacji postindustrialnej), tj. w procesach industrializacji, urbanizacji, w wyniku intensywnego rozwoju nauki i techniki (automatyzacji i robotyzacji), które spowodowały znaczące przeobrażenia społeczno-ekonomiczne i kulturowe. Drugie dotyczą tradycyjnej obyczajności, desakralizacji małżeństwa, które są wynikiem kultury masowej i oddziaływania mediów.

Według pierwszej orientacji „winna” rozpadu rodziny jest współczesna cywilizacja, niosąca nieuchronną zagładę, a w najlepszym wypadku radykalną przemianę wszelkich wartości i instytucji funkcjonujących w kulturach minionych. W mniemaniu zwolenników drugiej odpowiedzialność za obecną sytuację rodziny ponoszą nieudolny system wychowawczy, komercjalizacja życia, a także wzorce medialne.

Najpowszechniejszym podziałem czynników dezintegrujących rodzinę ze względu na źródła zagrożenia jest podział na czynniki wewnątrz-

16 Zob. szerzej na ten temat: T. Olearczyk, Rodzina miedzy starym a nowym paradygmatem, dz. cyt., s. 111-115. 
i zewnątrzrodzinne. Posłużę się (za Pilchem) następującym podziałem, zaznaczając, że nie jest on wyczerpujący, gdyż dotyczy zjawisk społecznych, a te nie są poddawane ścisłym podziałom i klasyfikacjom.

\section{Czynniki wewnątrzrodzinne integracji lub dezintegracji \\ Czynniki zewnątrzrodzinne integracji lub dezintegracji}

1. Cechy indywidualne członków rodziny.

2. Układ międzyosobniczy, hierarchia wewnątrzrodzinna.

3. Jakość, istota więzi emocjonalnych w rodzinie.

4. Cele i system wartości małżeństwa.
1. Polityka socjalna państwa wobec małżeństwa i rodziny.

2. Ideologia społeczna środków masowego przekazu.

3. Przemiany kultury i wykształcenia społeczeństwa.

4. Procesy uprzemysłowienia oraz związana z nimi ruchliwość przestrzenna i pionowa społeczeństwa.

\section{Organizacja życia rodzinnego} i podział obowiązków.

Źródło: T. Pilch, Wprowadzenie do andragogiki, red. T. Wujek, Warszawa 1996, s. 111.

Powyższa klasyfikacja ma uniwersalne właściwości i zastosowania. Dopiero w kontekście danego społeczeństwa nabiera innego znaczenia, zarówno dla systemu społeczno-politycznego, kultury, jak i poszczególnych członków rodziny. Dzieci w rodzinie są raczej biernymi odtwórcami zdarzeń. To dorosły w największym stopniu odgrywa czynną rolę, niekiedy inicjując zagrożenie, niekiedy mu zapobiegając.

\section{Deficyt wiedzy pedagogicznej}

Brak efektywnego systemu przygotowania do życia w rodzinie jako objaw dysfunkcyjności rodziny to również czynnik zagrażający jej integracji. Uwidacznia się również wyraźna emancypacja dzieci, a zwłaszcza młodzieży, zwiększył się zakres swobody i niezależności młodych ludzi. Relatywnie 
zmniejszył się za to świadomy wpływ rodziców na dzieci, chociaż wpływy wewnątrzrodzinne pozostają nadal silne. W wyniku skomplikowanej sytuacji współczesnego świata proces wchodzenia młodej generacji w życie społeczne często bywa zaburzony; trudności wychowawcze sygnalizowane są dość powszechnie (np. liczby spraw w sądach opiekuńczych, wykroczenia, przestępczość nieletnich, narkomania). Złożoność współczesnego świata, konflikty i sprzeczności utrudniają młodym proces adaptacji społecznej. Jeżeli nie mają oni oparcia w rodzinie, gubią się i w brutalny sposób stykają z rzeczywistością. A rodzina - zdaniem W. D. Walla - ma spełniać szczególną funkcję „niwelatora wstrząsów, filtru i pomostu”17.

Ludzkość jak dotąd nie wypracowała innej instytucji, która mogłaby w pełni, skutecznie zastąpić rodzinę, gdyż: „Szczęśliwe [jest] młode stworzenie, które ma prawo odczuwać i odczuwa miłość rodziców, serdecznych opiekunów, bliskich, własnych, pewnych, które ma dom rodzinny, gdzie może się schronić, ilekroć otoczenie poza tym domem powieje obcością"18.

Zainteresowanie rodziną jest obecnie niezwykle żywe i powszechne, gdyż to najbardziej pierwotna i naturalna grupa społeczna dla prawie każdego z nas. Pochłonięci obowiązkami, zapominamy o wartości, jaką niesie ze sobą. Kontakt $\mathrm{z}$ bliskimi osobami odgrywa istotną rolę w kształtowaniu osobowości człowieka, zaspokaja najważniejsze jego potrzeby: miłości i bezpieczeństwa. Dobrze funkcjonująca rodzina jest w stanie odpowiedzieć na potrzeby zarówno dzieci, jak i własne. Podział ról wychowawczych i zadań domowych między matkę i ojca nie ma znaczącego wpływu na rozwój dziecka, przynieść może za to obustronne korzyści. W Polsce rodzina zawsze odgrywała ważną rolę. Ugruntowało się także przekonanie, że ojciec jest osobą decyzyjną, matka natomiast była osobą wykonującą decyzje. Wraz z rozwojem cywilizacji coraz bardziej powszechne i dostępne stały się wolność w związku oraz możliwość wyrażania swojego zdania. Kobiety zaczęły stopniowo przejmować funkcje mężczyzn i zaskakująco dobrze sprawdzać się w nowej roli. Następuje maskulinizacja zachowań kobiecych i feminizacja męskich. Mężczyźni znakomicie opiekują się małymi dziećmi, a kobiety wykonują męskie zawody, co kiedyś było nie do pomyślenia. Są one partnerami w życiu prywatnym i zawodowym. Wiele czynności, które

17 W. D. Wall, Wychowanie i zdrowie psychiczne, tłum. M. Przetacznikowa, Warszawa 1960, s. 38 .

18 T. Kotarbiński, Medytacje o życiu godziwym, Warszawa 1986, s. 99. 
wykonywały kobiety, przejmują dziś mężczyźni, zmieniła się też funkcja domu (kuchni) - rodzina coraz częściej spożywa posiłki poza domem, nie traci czasu na gotowanie, a wykorzystuje go na wypoczynek, rozrywkę.

W małżeństwie ważny jest pierwiastek duchowy. To on bowiem spaja małżeństwo. Bywa, że ślub kościelny jest ostatnią „deską ratunku” przed rozwodem. Wiara odgrywa dużą rolę w spójności i trwałości małżeństwa. Od dojrzałości małżonków zależy podjęcie decyzji co do trwania w związku lub rozejścia się. To oni mają wpływ na jakość swojego małżeństwa. Warto zatem uczyć się bycia ze sobą i pamiętać, że długotrwały związek to ogromna szansa rozwoju.

\section{Pokolenie "covidów" - szansa na nowe myślenie, nowy styl życia}

Covid-19 wstrząsnął światem. Przyniósł najpierw lęk, a potem nadzieję, że pandemia szybko minie. Może zatem przyniesie refleksję, że warto żyć nieco ciszej i spokojniej, że życie trzeba p r z e ż y ć, a nie przebiec, że powinniśmy na nowo ułożyć hierarchię wartości, przypomnieć sobie sens i cel życia, znaleźć czas, by wysłuchać bliskich. Potrzebna jest nam cisza refleksji.

Rośnie pokolenie „covidów” - osób dorastających w zagrożeniu. To ono zbuduje nowy świat, na nowych zasadach. Nie ma powrotu do przeszłości, nie wrócą się dni ani godziny, będziemy żyć w innych warunkach - nie tylko społeczno-politycznych, ale i przyrodniczych, klimatycznych, w innych, „zdalnych” relacjach. To zaś oznacza, że nadchodzą trudne czasy, ale także - a może przede wszystkim - że będziemy mieć dostęp do nieprawdopodobnie bogatej palety uczuć, przeżyć i odkryć . To czas młodych, prawych ludzi i wiedzy.

\section{Podsumowanie}

Przemiany dokonywały się zawsze i dokonują teraz, tyle że dziś odbywa się to w znacznie szybszym tempie - dzięki globalizacji, rozwojowi techniki, 
internetowi, wykształceniu, podróżom. Mobilność społeczeństwa przyczyniła się w pewnym sensie do zmiany relacji w rodzinach i kontaktach z bliskimi. Kształtują się nowe formy życia rodzinnego, zmieniła się też religijność współczesnego człowieka. Pozostały jednak potrzeby, a wśród nich te najważniejsze - miłości i bezpieczeństwa. Niezmiennie Prawda pozostanie prawdą, a Miłość miłością - ważne, by nie wypaczać treści, które te słowa zawierają. Młode pokolenie ma szanse, by napełnić świat nową myślą, refleksją i dobrą energią. Na świecie zawsze będzie dobro i zło, ale wyboru dokonuje człowiek, a miłość jest solą życia.

Reasumując, należy stwierdzić, że rodzina zmienia się pod względem kulturowym, ulega licznym wpływom, jednak jej problemy od wieków pozostają takie same. W przeszłości jednak nie zawsze były głośno i wyraźnie artykułowane, ze względu na mniejszy dostęp do wiedzy i informacji, nie zawsze wiedziano też, gdzie szukać pomocy. Jedyną dostępna ucieczką były wiara i modlitwa, które i dzisiaj są w zasięgu ręki. Tyle tylko, że dziś coraz więcej jest wiedzy, a coraz mniej prawdziwej wiary. Czas to naprawić.

\section{Bibliografia}

Cisza w teorii i praktyce. Obraz interdyscyplinarny, red. T. Olearczyk, Kraków 2014.

Czuba K., Idea Europy kultur w nauczaniu Jana Pawła II, Warszawa 2003.

Doniec R., Rodzina wielkiego miasta. Przemiany społeczno-moralne w świadomości trzech pokoleń, Kraków 2001.

Dyczewski L., Rodzina polska i kierunki jej przemian, Warszawa 1981.

Franciszek, Dar odnowionej bliskości między rodzina a Kościołem, „L'Osservatore Romano" 10 (2015) wyd. pol., s. 48-49.

Giddens A., Konsekwencje nowoczesności, tłum. E. Klekot, Kraków 2008.

Kawula S., Diagnozowanie potrzeb opiekuńczo-wychowawczych środowiska rodzinnego, Toruń 1978.

Kieniewicz S., Dramat trzeźwych entuzjastów. O ludziach pracy organicznej, Warszawa 1964.

Kopciewicz L., Kobiecość, męskość i przemoc symboliczna. Polsko-francuskie studium porównawcze, Kraków 2005. 
Kotarbiński T., Medytacje o życiu godziwym, Warszawa 1986.

Le Bon G., Psychologia tłumu, tłum. B. Kaprocki, Kraków 2018.

Obrzut A., Rola ojca w rodzinie, www.psychorada.pl/news,rola-ojca-w-rodzinie.html (28.05.2020).

Olearczyk T., Rodzina między starym a nowym paradygmatem, Rużomberk 2013.

Olearczyk T., Sieroctwo i osamotnienie. Pedagogiczne problemy kryzysu współczesnej rodziny, Kraków 2007.

Olearczyk T., Prawa dziecka we współczesnej praktyce życia społecznego, Częstochowa 2001.

Olearczyk T., Współczesne uwarunkowania procesu wychowawczego, w: Rodzina i edukacja w zmaganiu o przyszłość Europy, red. E. Osewska, Tarnów 2016, s. 129-148.

Olearczyk T., Wychowawcze funkcjonowanie współczesnej rodziny polskiej, Częstochowa 2001.

Piwowarski T., Rodzina jako społeczność naturalna wg. św. Tomasza $z$ Akwinu, „Roczniki Filozoficzne” 8 (1960), z. 2, s. 89-111.

Rembowski J., Więzi uczuciowe $w$ rodzinie. Studium psychologiczne, Warszawa 1972.

Renzetti C. M., Curran D. J., Kobiety, mężczyźni i społeczeństwo, Warszawa 2005.

Szlendak T., Socjologia rodziny. Ewolucja, historia, zróżnicowanie, Warszawa 2010.

Terakowska D., Bomba J., Być rodzina - czyli jak budować dobre życie swoje i swoich dzieci, Kraków 2003.

Truchanowicz M., Męska kobieta, kobiecy mężczyzna - współczesne postrzeganie ról płciowych, www.psychologszczecin.pl/a1307037952pol-Meska-kobieta-kobiecy-mezczyzna.html (28.05.2020).

Wall W. D., Wychowanie i zdrowie psychiczne, tłum. M. Przetacznikowa, Warszawa 1960. 